\title{
Lumen
}

Selected Proceedings from the Canadian Society for Eighteenth-Century Studies

\section{Sure John Rich could read: but could Lun dance?}

\section{Richard Semmens}

Volume 31, 2012

URI : https://id.erudit.org/iderudit/1013074ar

DOI : https://doi.org/10.7202/1013074ar

Aller au sommaire du numéro

Éditeur(s)

Canadian Society for Eighteenth-Century Studies / Société canadienne d'étude du dix-huitième siècle

ISSN

1209-3696 (imprimé)

1927-8284 (numérique)

Découvrir la revue

Citer cet article

Semmens, R. (2012). Sure John Rich could read: but could Lun dance? Lumen,

31, 155-168. https://doi.org/10.7202/1013074ar

Copyright (C Canadian Society for Eighteenth-Century Studies / Sociéte canadienne d'étude du dix-huitième siècle, 2012
Ce document est protégé par la loi sur le droit d'auteur. L'utilisation des services d'Érudit (y compris la reproduction) est assujettie à sa politique d'utilisation que vous pouvez consulter en ligne.

https://apropos.erudit.org/fr/usagers/politique-dutilisation/ 


\title{
Sure John Rich could read: but could Lun dance?
}

\author{
Richard Semmens \\ University of Western Ontario
}

It has been said of John Rich (1692-1761)

that he was the London manager most responsible for popularizing the variety bills so typical of the eighteenth-century theatres in London. From the very opening of his Lincoln's Inn Fields playhouse [in late 1714] Rich recognized the pleasure his audiences received in seeing something more than just a play during an evening's entertainment... ${ }^{1}$

Among the most successful of the entertainments Rich incorporated into his offerings were those that featured harlequinades in which Rich himself, under the stage name Lun after 1717 , performed the mute role of Harlequin. Rich was not alone in tapping into the noteworthy popularity of harlequinade entertainments, commonly referred to as pantomimes by modern scholars: the managers of the Drury Lane company were quick to respond in kind. ${ }^{2}$ No other manager, however, was as actively engaged in the actual performance of pantomimes as was Rich, and his performances continued to great applause well after his company's move to the newly constructed Covent Garden theatre in 1733 .

1. Philip H. Highfill, Jr., Burnim, Kalman A., and Langhans, Edward A., A Biographical Dictionary of Actors, Actresses, Musicians, Dancers, Managers 6 other Stage Personnel, 1660-180o (Carbondale: Southern Illinois UP, 1987), vol. 12, 338.

2. For a useful review of literature and thoughtful assessment, see John O'Brien, Harlequin Britain: Pantomime and Entertainment, 1690-176o. Baltimore, MD: Johns Hopkins UP, 2004. 
Pantomime productions in London during the 17-teens, -twenties and -thirties were often referred to as "dances" in the popular and critical presses. ${ }^{3}$ From surviving cast lists it is clear that many of the leading professional dancers of the day participated, and the evidence suggests that they danced in both serious and comic styles with great skill. In his review of some of the famous English dancers of his time and the recent past, for example, John Essex remarked in 1728 that "the Performers upon both Stages [Drury Lane and Lincoln's Inn Fields] at this Time are very eminent in Serious as well as Comic." ${ }^{\prime 4}$ And while a pantomime almost always featured sung items, often located within scene units not dedicated to mimed and dance action, ${ }^{5}$ the decision to sometimes call the whole show "a dance" is certainly understandable: movement (of several varieties) accompanied by music was a dominant component. It is hardly surprising that John Rich has come to be regarded in recent scholarship as a great dancer. ${ }^{6}$ Was he?

Some of the surviving pictorial evidence might lead one to conclude that Lun was a dancer of considerable prowess. Perhaps the most frequently reproduced depiction of John Rich as a dancer is an engraving from the collection of the Garrick Club in London (see Illustration 1 below). ${ }^{7}$ It has recently been uncovered as a counterfeit. ${ }^{8}$ The source

3. Among many such references, see the satirical piece in The Anti-Theatre, by John Falstaffe Issue 12 (1720), where we find the following: "there is preparing a Dramatic Pantomime, called 'The Quadruple Alliance'... The Dance is to be performed by four."

4. John Essex, The Dancing master, or the art of dancing explain'd (London, 1728), xiii. Although a handful of notated choreographies of the period can be linked with good certainty to other kinds of afterpiece entertainment, no dances from a pantomime have yet to be uncovered.

5. See Paul Sawyer, "Smorgasboard on Stage: John Rich and the development of eighteenth-century pantomime." The Theatre Annual 34 (1979): 37-65.

6. One scholar has remarked, "Rich's choice of John Ernest Galliard's music and his utilization of his own considerable talents as a dancer were significant elements in its [Rich's pantomimes] successes." See Phyllis T. Dircks, "The eclectic comic genius of John Rich in The Necromancer," Theatre Notebook. A Journal of the History and the Technique of the British Theatre 49/3 (1995), 165. In John McVeagh, "The Subject of almost all companies': A new look at The Necromancer," Theatre Notebook 45/1 (1991), 66, I find the following claim, one that simply is not supported by the surviving documents: "Every observer of the time praised Rich's skill as a dancer and mime artist" (my emphasis).

7. Catalogue number PMo153.

8. Iain Mackintosh (with Marcus Risdell), "John Rich Unmask'd Off and On Stage," paper presented at the conference entitled John Rich and the Eighteenth 
engraving is a seventeenth-century French Harlequin by Nicholas Bonnart, newly transposed onto a selection of background scenes from one of Lun's most famous roles in The Necromancer, or Harlequin Doctor Faustus, first performed in late 1723. Clear evidence of the forgery can be seen in the half-mask this Harlequin wears: Lun and other Harlequinade performers in England, on the other hand, wore full masks when they wore them at all, as does Lun in this second depiction, dating from 1753 (see Illustration 2). ${ }^{9}$ Depictions such as these are idealized, presenting a figure abstracted from any stage action, but possessing the mechanics and look of a professional dancer. The only image (known to me) of Lun that contextualizes him in pantomime performance, again in The Necromancer, is one from the collection of the British Museum, ${ }^{10}$ and here he looks like an actor, not a dancer (see Illustration 3 below). In this scene, from early in the entertainment, Richard Leveridge as the Infernal Spirit tries to convince Doctor Faustus to sign a pact with the Devil to acquire magic powers. Leveridge was a singer, who in fact had just sung, or perhaps was about to sing the aria "Arise ye subtle Forms" (Furies, performed by professional dancers). But neither Leveridge nor Lun danced here. Moreover, Lun is not masked, although the checkerboard pattern of his Harlequin costume is clearly visible, even if partially concealed by a long cloak that drapes over his left shoulder. The cloak, along with his floppy, wide hat, are probably intended to project the other half of his persona: Dr. Faustus. Did Lun dance in this production after he agreed to sign the pact? Did he ever dance? I will argue in what follows that John Rich/Lun could not dance, or if he could, he never did so professionally.

In 1712 John Weaver theorized three broad categories in which dance might be understood: "serious," "grotesque," and "scenical." He cast his net over a wide territory of movement possibilities that he regarded as belonging to the dancer's art, or the dancing master's science. Serious dancing was something to admire for its grace, its strength and control, its symmetrical shapes, and its pleasing quality:

Century London Stage: Commerce, Magic, and Management (26-27 January, 2008). An abstract of the presentation can be found at http://www.johnrich2008. com/ Abstracts\%201.html. (Accessed June, 2010).

9. Also from the Garrick Club, Catalogue number Go716.

10. British Museum, Inventory AN290264001. 
it was a category that embraced both ballroom dancing by gifted (usually noble) amateurs, and professionals, who were obliged to make it somehow "bigger" in theatrical performances. Grotesque dancing aimed to convey or express something: the "manners" or the "passions" or the character of a particular historical figure, or a generalized state of feeling. Scenical dancing told a story, was narrative: in Weaver's vision this category tried to approach the fabled (for him) pantomimes of the ancients. ${ }^{11}$ Weaver never claimed that his three categories could not operate together. He never favoured one over the other (although his personal agenda in creating danced entertainments might be argued to prefer scenical dancing). By 1728 , on the other hand, Weaver revised his categorization of dancing styles, likely in response, if only in part, to the great popularity comic pantomime or "grotesque" entertainments had acquired. Now he elected to classify all dancing as either serious or grotesque. ${ }^{12}$ In the new scheme serious dancing was a conflation of his formerly segregated "serious" and "grotesque" categories, but with one important difference: comic dances seem to have been expunged (the new category, after all, is "serious dancing"). Weaver confined his new classification of grotesque dancing, likely a cynical one, to "only such Characters as are quite out of Nature; as Harlequin, Scaramouch, Pierrot, \&c," [that is performers in the harlequinades], "where, in lieu of regulated Gesture, you meet with distorted and ridiculous Actions." But he allowed that among other dancing masters grotesque dancing "takes in all comic Dancing whatever."13

In neither of Weaver's schemes is there any suggestion that a dancer might specialize in just one dancing style (the vagaries of type-casting notwithstanding); rather, it seems, the dance styles he identified belong to the dancer's whole art, they are a part of her or his formation as a professional. This conception of the dancer's arsenal of skills was longlived. They were confirmed, for example, in Gennaro Magri's Trattato teorico-prattico di ballo of 1779, perhaps the most comprehensive treatment of theatrical dancing practices published during the century. Although less concisely than Weaver, Magri referred to the three broad

11. John Weaver, An Essay towards an History of Dancing (London, 1712), 158-69.

12. John Weaver, The History of the Mimes and Pantomimes (London, 1728), 55-56.

13. Weaver, The History of the Mimes and Pantomimes, 56. 
categories of his art as serio, mezzo carattere, and grottesco. ${ }^{14}$ All three were expressive, but the style of mezzo carattere conveyed passions and characterizations in a less athletic way than that practised by a grottesco, who incorporated acrobatic gestures often featuring leaps of exceptional height. Additionally, the grotteschi were invariably associated with pantomimic representation. ${ }^{15}$ Like Weaver, Magri allowed a two-fold division of the dancing arts as well:

The true Ballerini, whether Seri or Comici must equally be in general possession of everything pertaining to dancing; no real distinction can be made between one Character and another, for if it is difficult to dance the serio it is no easier to dance the truly light comic... ${ }^{16}$

A wide-ranging set of skills and technique was expected of the professional dancer in the eighteenth century, and although details of choreographic invention and specifics about preferred execution varied over place and time, the basic conception of dancing styles and a dancer's versatility remained remarkably stable across the continent and the century. It is within this theoretical framework that I will assess Rich's performances on the London stage.

My focus will be on The Necromancer, and I will begin with a consideration of some of the dancers who shared the stage with Lun in the quite astonishingly successful opening run. The original cast list is given below.

Example 1. Cast list of The Necromancer, or Harlequin Doctor Faustus as presented in the 1724 Exact Description. ${ }^{17}$
Doctor Faustus
Mr. Rich
Infernal Spirit
The Five Furies
Mr. Leveridge
$<$ Mr. Dupre
$<$ Mr. Nevelon, sen.

14. Magri's career and his treatise have been thoroughly re-examined and reassessed recently in Rebecca Harris-Warrick, and Bruce Alan Brown, eds. The Grotesque Dancer on the Eighteenth-Century Stage. Gennaro Magri and his World (Madison, Wisconsin: U of Wisconsin P, 2005).

15. For a useful overview of Magri's classification see Rebecca Harris-Warrick, "Introduction," 6-12, in The Grotesque Dancer.

16. Quoted in Harris-Warrick, "Introduction," 12.

17. An Exact Description of the two fam'd Entertainments of Harlequin Doctor Faustus... and the Necromancer, or Harlequin Doctor Faustus, as now Perform'd in Grotesque Characters at both Theatres (London, [1724]). 
The Shade of Helen

The Doctor's Man

Two Men in the fifth scene

The Miller

His Wife

His Man

Leander

Hero

Charon

Harlequin Man and Woman

Punch Ditto

Scaramouch Ditto

Mezzetin Ditto
$<$ Mr. Nevelon, jun.

$<$ Mr. Lanyon

$<$ Mr. Newhouse

Mrs. Chambers

Mr. Spiller

$<$ Mr. Nevelon, sen.

$<$ Mr. Nevelon, jun.

Mr. Nevelon, sen.

Mrs. Rogier

Mr. Nevelon, jun.

Mr. La Guerre

Mrs. Chambers

Mr. Leveridge

$<$ Mr. Dupre

$<$ Mrs. Rogier

Mr. Nevelon, sen., Mrs. Hall

Mr. Lanyon, Mrs. Ogden

Mr. Nevelon, jun., Mrs. Cross

Mr. Dupre is Louis Dupré who first danced at the newly reopened Lincoln's Inn Fields theatre in 1714. More notated dances in which he was a named performer survive for him than for any other male dancer on the London stages. These choreographies require a very high level of skill and agility, and in one - a solo for Dupré - a remarkable feat of control and strength as well (see illustration 4). The final eight measures of the dance include a series of pirouettes, all of them taken on the left foot. The first is a virtuoso pirouette that carries the dancer two complete rotations in a clockwise direction (en dehors) and, moreover, the rotations are at a very controlled speed, for they are to occupy two full measures of music! The weight still on the left foot in demi-pointe, a second pirouette begins, this time only a single rotation (again en dehors), but with three battements taken by the free foot - en avant, en arrière, and en avant - all concluding with tour de jambe flourish. This pirouette is then repeated, but its concluding flourish calls for an additional ronde de jambe. After four measures and four complete rotations, the weight continuously on the left foot, the dancer is finally allowed to come off demi-pointe, for a well-deserved measure of stabilizing jettés-chassés. This choreography makes it abundantly clear that Dupré was a consummate artist. But he was also an accomplished comic dancer, much applauded, in particular, for his performances as 
a Harlequin. The only engraved notation of a dance for Harlequin, in fact, is dedicated to Dupré by the choreographer (and engraver) who explains how he has tried to incorporate some of the gestures Dupré was famous for. ${ }^{18}$ Dupré took on two roles in The Necromancer, one of the five Furies we have already briefly encountered, and a Harlequin in a grouping of four Harlequinade demon couples, who propel us through the action of the entertainment's rather gruesome finale, in which Dr. Faustus is chewed up by a stage dragon.

The Nevelons, Sr. and Jr., were the brothers Francis and Louis Nivelon, recently arrived from Paris for the opening of John Rich's 1723-24 season. Francis enjoyed a very successful performing career in London through the 1738-39 season, but his younger brother, it appears, returned to Paris after a single season with Rich. Francis became a regular member of Rich's company in the 1724-25 season, drawing a very substantial salary of $£_{5}$ per day. ${ }^{19}$ The Nivelon brothers made significant contributions to The Necromancer, performing in all but one of the scene-units featuring dance. They joined Dupré as Furies, and in the Harlequinade finale. But they also provided a moment of comic acrobatics in what one source called the "fifth scene" of the production. The Doctor has told the fortunes of two men who have come to visit, disclosing that they shall both be hanged. The two refuse to pay the Doctor's fee for such a fortune, and attempt to make their exit. But the Doctor waves his wand, and they are forced to return standing on their hands, in which position they are made to perform a minuet around the room. The Nivelon's were also featured performers in the famous windmill scene, Francis as the Miller, and Louis as his Man. Near the end of this scene the Miller, who has been chasing Harlequin Doctor Faustus for trying to seduce his wife, finds himself

18. F. LeRoussau, A Chacoon for a Harlequin. With all the Postures, Attitudes, Motions of the Head and Arms and other Gestures proper to this Character (London: nd, [c1728]). Part of the dedication to Dupré reads: "My chief design being to describe on paper the postures which are most in practice for the Harlequin, I have endeavoured to represent some of yours."

19. As reported in A Biographical Dictionary, vol. 11, 33. This source provides a translation of a vivid account of one of Francis Nivelon's performances found in Claude Parfaict, Dictionnaire des theaters de Paris (Paris, 1767), Tome III, 503. It is quite clear from Parfaict's account, however, that the Nivelon being described cannot be Francis of London: Parfaict's Nivelon, rather, is performing in Paris in 1728 and 1729 . 
hanging on to the rotating sail of the windmill until his Man can help him escape. I will return to this scene, because it may be the only one in which Rich might be argued to have danced.

Brief mention, finally, must be made of Mrs. Rogier. Her maiden name remains unknown, but after 1721 Mary was wife to a John Rogier until his death in $1724 .{ }^{20}$ Thereafter she was married to John Laguerre who had sung the role of Leander in The Necromancer. Mrs. Rogier was both actor and dancer, a skills combination that was only encountered sporadically. But her talent as a dancer must have been considerable, for the playbills frequently have her paired with Nivelon. ${ }^{21}$ Mrs. Rogier was the only dancer among the eight who took part in The Necromancer to have been assigned a solo, this performed at the opening of the windmill scene by the Miller's Wife: “The Miller's Wife," a contemporary wordbook tells us, "comes down the Stairs from the Mill, and dances." 22 Mrs. Rogier also participated in the final scene Harlequinade, paired with Louis Dupré as male and female Harlequin demons.

Printed descriptions of pantomime entertainments almost never give cues for dancing. ${ }^{23}$ The Necromancer is a happy exception, for a number of its published accounts give very precise information about when a dance was performed and by what characters. It is based on this information that I have been able to describe very briefly in the foregoing just where Dupré, the Nivelon brothers, and Mrs. Rogier were given opportunities to shine as dancers in the production. These printed accounts are quite unequivocal, however wanting in detail, in locating dances. Of the dance for five Furies that included Dupré and the two Nivelons, for eample, we find "Here Furies rise and Dance,

20. Information drawn from A Biographical Dictionary, vol. 9, 118.

21. An anonymous engraving, reproduced in A Biographical Dictionary (vol. 9, 118), depicts the pair dancing together in Perseus and Andromeda, first performed in 1730. The original cast list, however, suggests that Mrs. Lagare (LaGuerre) and Nivelon did not work together, but rather in separate parts of the production. See Perseus and Andromeda. As it is perform'd at the Theatre Royal in Lincoln's-Inn-Fields (London, 1730).

22. An Exact Description, 29.

23. Exceptions besides The Necromancer include the rival production of Harlequin Doctor Faustus (1723) at Drury Lane, four serious pantomimes by John Weaver offer good precision about the location of dances: The Loves of Mars and Venus (1717); Orpheus and Eurydice (1718); Perseus and Andromeda, with the Rape of Colombine or, The Flying Lovers (1728); and The Judgment of Paris (1733). 
and then vanish." ${ }^{24}$ After Mrs. Rogier, as the Miller's Wife, has performed her solo dance (see note 23), another account informs us "Then comes the Miller [Francis Nivelon] who at first seems angry, but is immediately reconcil'd, and dances along with her." 25 But the sources simply do not link any dancing with the character of Harlequin Doctor Faustus. Rather, we find him as the architect (and sometimes the object) of stage tricks, and the animateur of danced or sung items. He is, in other words, the primary focus of mimed action. The single exception is a description of the closing moments of the windmill scene, after the Miller has been rescued by his Man from the windmill's sail. Only two of the surviving printed sources describe this action, one of which reads: "Then enter to 'em a Gygantick Figure, who beats them, upon which they draw their Knives, and cut off its Arms, then its Head. It still continues dancing, then they rip up its Belly, out of which jumps the Doctor, and beats them off..."26 The "dancing" here cannot have been very substantial, likely little more than a large stage figure (concealing the Doctor), rocking back and forth as various body parts are hacked off.

If Lun were a trained dancer, he did not exploit those skills in The Necromancer, in clear distinction to the documented activities of Dupré, or the Nivelons, or Mrs. Rogier in the production. Because printed descriptions of pantomime entertainments after 1723 are silent on the action of the comic parts - that is, those parts in which Lun was a featured performer - it is not possible to track any changes to protocols in place for The Necromancer in subsequent years. But other evidence suggests that Lun never danced as part of his celebrated performances. His contemporaries, and most importantly professional dancers active at the time evidently did not regard him as a dancer. Testimonials to gifted dancers such as the one by John Essex cited at the opening of this essay never mention Lun. The omission in the Essex testimonial (1728) is conspicuous because it lavishes particular praise on Mr. [John] Shaw (d. 1725). Shaw, of course, had played the title role in the Drury Lane Harlequin Doctor Faustus playing concurrently

24. An Exact Description, 23.

25. A dramatick entertainment called, The Necromancer: or, Harlequin Doctor Faustus. As perform'd at the Theatre Royal in Lincoln's-Inn-Fields (Dublin, 1725), 12. 26. A dramatick entertainment called, The Necromancer: or, Harlequin Doctor Faustus, 13. 
(frequently on the same evenings) with The Necromancer. Essex says of Shaw "He was very excellent in many Characters; the last he performed was Mercury in Dr. Faustus, which he did with ... Correctness and Truth in all its Attitudes." 27 Mercury appears as one of the dancers in the 'Masque of the Heathen Deities,' a concluding, serious appendage to the farce that precedes it, but Shaw danced as the Doctor in that farce, as well. He did not merely mime, like Lun, he danced, even as a soloist, as the printed descriptions make clear. In one scene the action is described as follows: "The Doctor enters alone, and having Danced a little Time, is accosted by his three Students." ${ }^{28}$ In another "He jumps on the Table, and admires his Leg, then jumps on the Ground, and dances to a brisk Tune." 29

Kellom Tomlinson (flip1os-30s), author of an important dancing manual first published in 1735, also singles out Shaw as worthy of praise as having been "one of the finest Theatrical Dancers" 30 of his day. But again Tomlinson makes no mention of Lun, even though he had rather close ties to Rich's Lincoln's Inn Fields Theatre. Tomlinson had created a mini-entertainment of dancing there for two of his pupils, John Topham, Jr., and Mrs. Schoolding, for a revival of The Island Princess mounted in May $1716 .{ }^{31}$ It is an irony that John Rich was one of the subscribers to Tomlinson's dance manual! Maybe he had designs on learning to dance one day, or maybe he simply wanted to help out an old friend and theatrical collaborator. ${ }^{32}$ Another publication that attracted subscriptions from several of the professional dancers who performed in the Harlequin Doctor Faustus productions at either Lincoln's Inn Fields or Drury Lane is noteworthy because John Rich

27. The Dancing Master, xiv.

28. An Exact Description, 5.

29. Harlequin Doctor Faustus, with the Masque of the Deities (London, 1724), 8.

30. Kellom Tomlinson, The Art of Dancing explain'd by reading and figures (London, 1735), "Preface," unpaginated.

31. The choreographies for Tomlinson's entertainment in dancing, in fact, have survived. See Jennifer Shennan, ed. A Workbook by Kellom Tomlinson. Commonplace Book of an Eighteenth-Century English Dancing Master, A Facsimile Edition (Stuyvesant, New York: Pendragon, 1992).

32. Some of the 'true' professional dancers involved in the rival Harlequin Doctor Faustus productions also subscribed to Tomlinson's dance manual undertaking, including Louis Dupré, and Mrs. Bullock and Mrs. Booth (Hester Santlow) from Drury Lane. 
was not among them. ${ }^{33}$ This publication, unlike Tomlinson's which was concerned with ballroom dancing, was a collection of theatrical choreographies "that have been performed both in Drury Lane and Lincoln's Inn Fields by the best Dancers." ${ }^{34}$ Issued around 1725, it is the single most important theatrical dance collection ever published in London, one that had neither precedent nor successor. The challenging solo passage for Louis Dupré (seen in Illustration 4) is drawn from one of the dances of the collection. If Lun really were a professional dancer he surely would have subscribed to its preparation and eventual publication, a singular monument to theatrical dance in his day. But he didn't. And he certainly was not named as a performer in any of the dances the publication transmits.

As Lun, John Rich must have moved with great effectiveness, comically preparing or responding in gesture to the stage antics and wizardry all about him. His skill was frequently remarked, but he was never regarded as a dancer by his contemporaries. While Weaver allowed that "distorted and ridiculous Actions" were part of a grotesque dancer's bag of tricks, he did not envision these as the only trick in the bag. It was, I am convinced, the only trick in Lun's bag.

Many of us, I am certain, can bring to mind the remarkable performances of the late Marcel Marceau. His exaggerated gestures, the playful convincingness of his actions (devoid, typically, of any special stage effects) were his art. But we don't think of him as a dancer. He wasn't, after all.

33. Among the subscribers we find: Mr. Shaw, Mr. Topham, Sr., Mr. Topham, Jr., and Mr. Boval, all of whom danced in the Drury Lane production; and Mr. Dupré, and Mr. Newhouse from John Rich's production.

34. A New Collection of Dances, containing a great Number of the best Ball and Stage Dances: Composed by Monsieur L'Abbé, Dancing Master to Their Royal Highnesses, the Three Young Princesses (London, [c1725]). Facs. Ed. by Carol Marsh (London: Stainer \& Bell, 1991). 
166 Richard Semmens

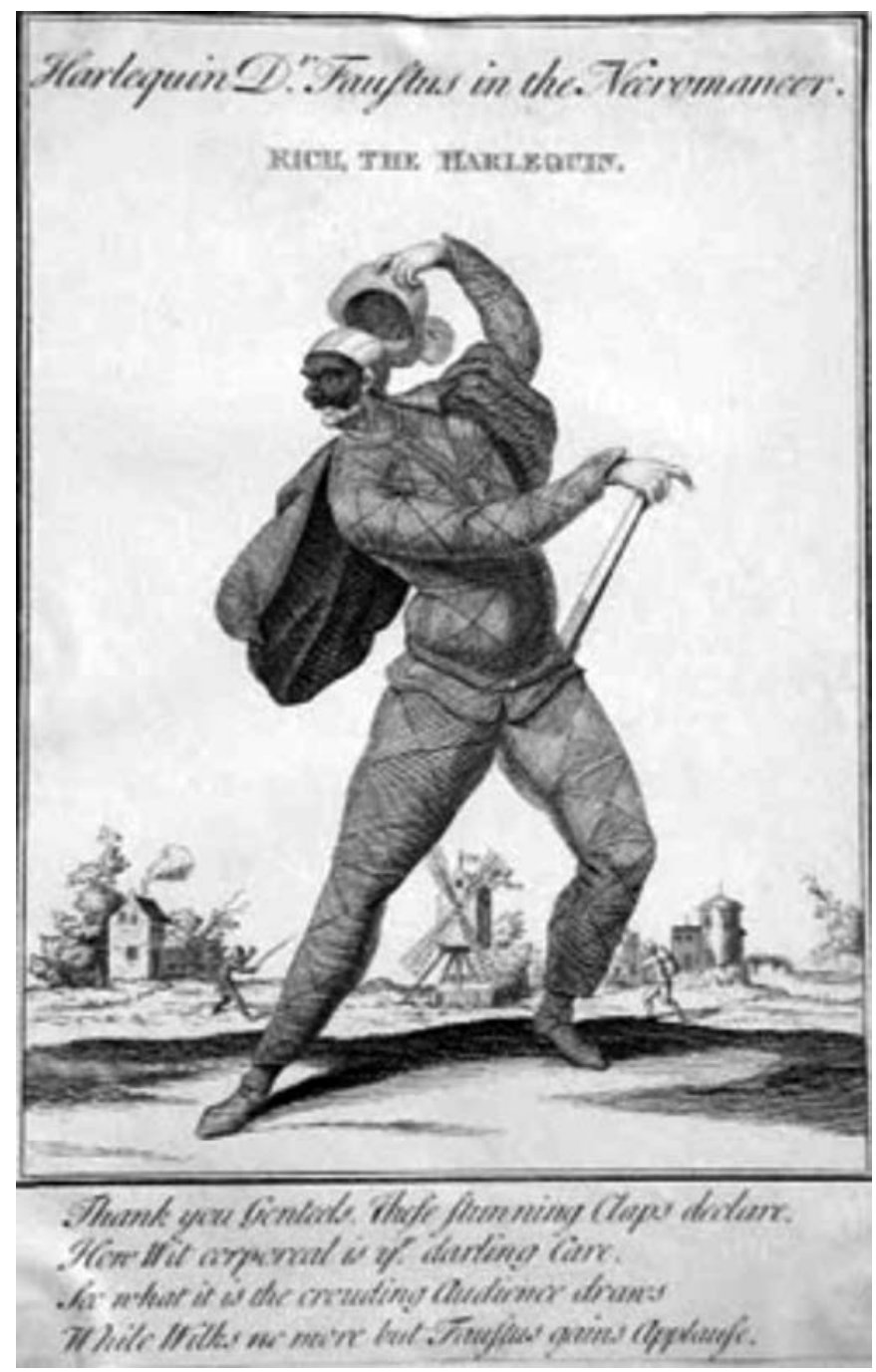

Illustration 1: Forged engraving of John Rich in The Necromancer. Undated (courtesy of the Collection of the Art Archive / Garrick Club, PMo154). 
Sure John Rich could read: but could Lun dance? \$ 167

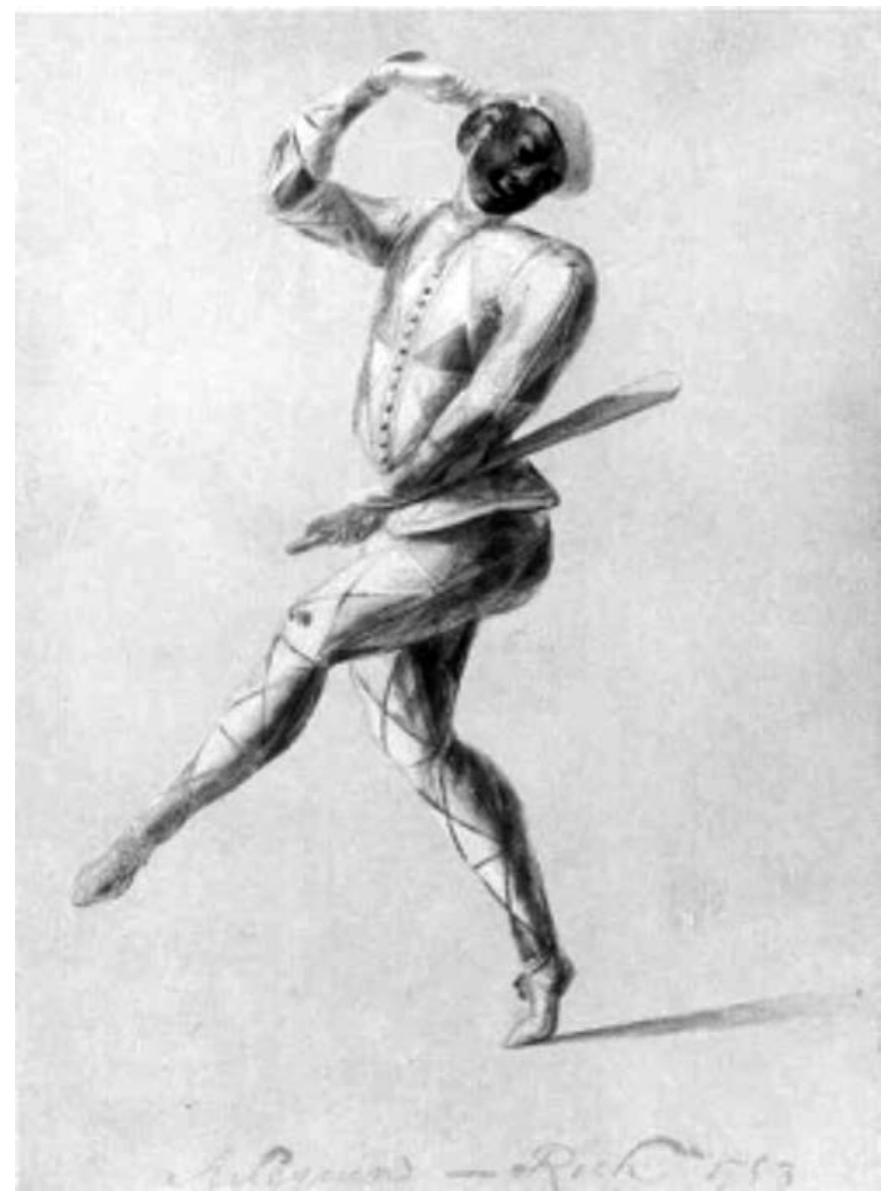

Illustration 2: John Rich in 1753. Artist unknown (courtesy of the Collection of the Garrick Club, Go716). 


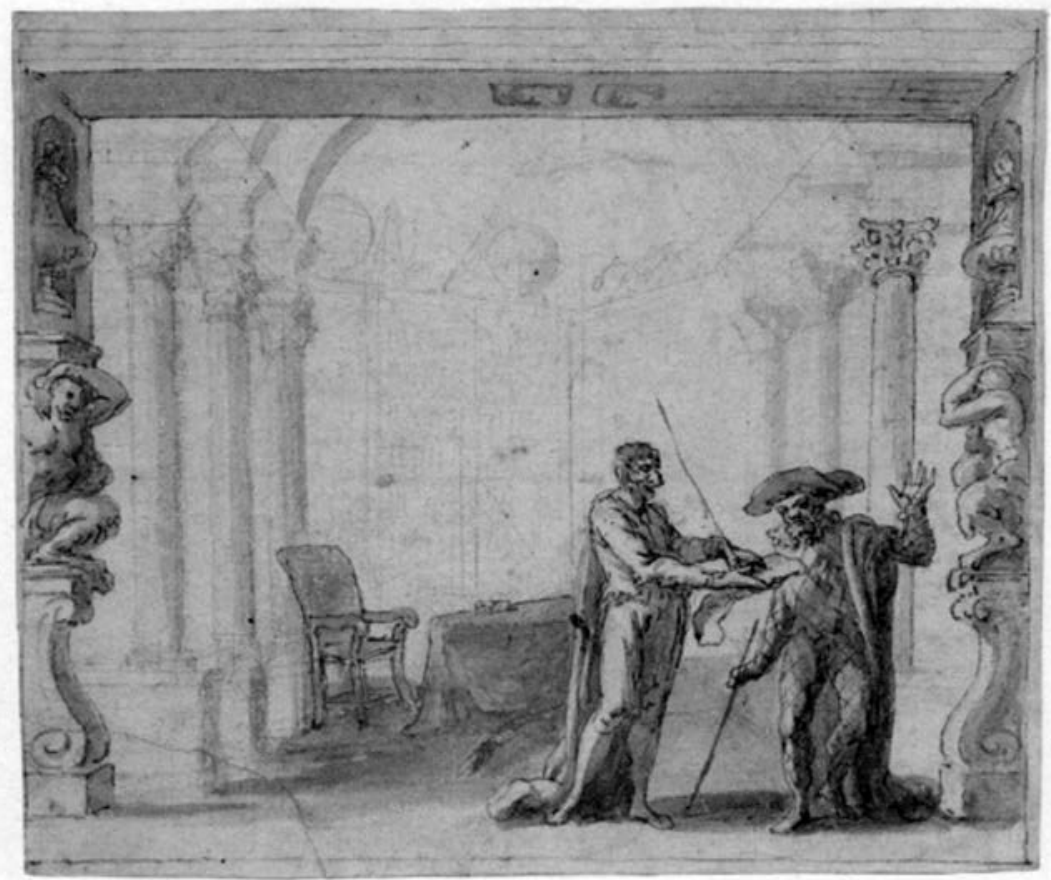

Illustration 3: John Rich with Richard Leveridge as the "Infernal Spirit" in The Necromancer, or Harlequin Doctor Faustus. c. 1724. Artist unknown (collection of the British Museum, AN290264001, (C) Trustees of the British Museum).

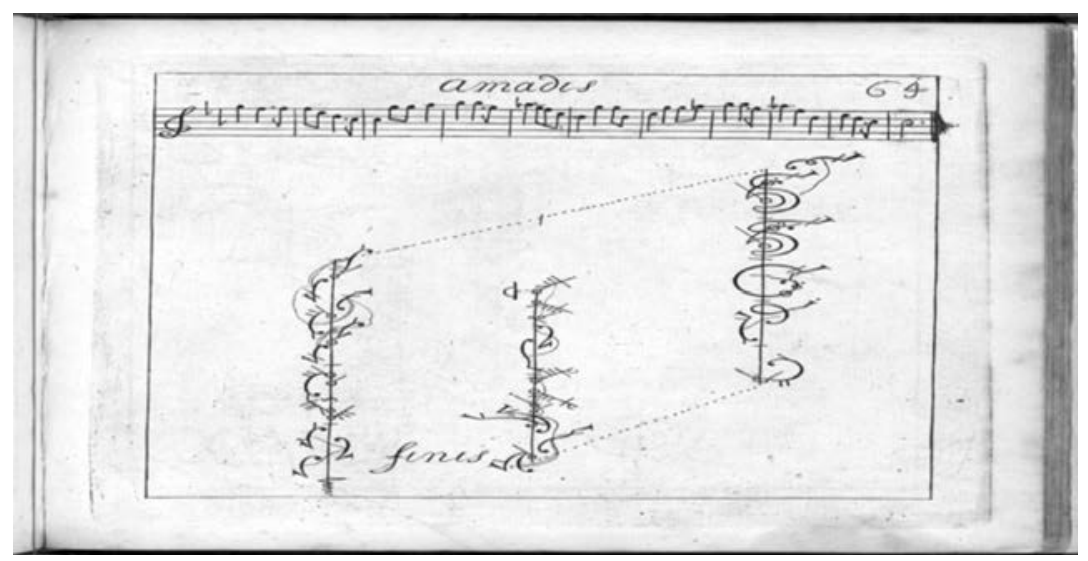

Illustration 4: Final figure from the "Chacone of Amadis Perform'd by Mr. Dupré," Anthony L'Abbé. A New Collection of Dances, London, c. 1725, 64. The dance passage in question is notated on the right hand side of the page (from TS 552.13.55.1, courtesy of Houghton Library, Harvard University). 